\title{
MITOCHONDRIAL DYSFUNCTIONS AND ANTIHYPOXANTS
}

\author{
УДК 616-092.18:615.03 \\ https://doi.org/10.7816/RCF17431-42
}

\author{
() V.E. Novikov ${ }^{1}$, O.S. Levchenkova ${ }^{1}$, E.N. Ivantsova ${ }^{1}$, V.V. Vorobieva ${ }^{2}$ \\ ${ }^{1}$ Smolensk State Medical University, Smolensk, Russia; \\ ${ }^{2}$ Kirov Military Medical Academy, Saint Petersburg, Russia
}

For citation: Novikov VE, Levchenkova OS, Ivantsova EN, Vorobieva VV. Mitochondrial dysfunctions and antihypoxants. Reviews on Clinical Pharmacology and Drug Therapy. 2019;17(4):31-42. https://doi.org/10.17816/RCF17431-42

Received: 02.10.2019

Revised: 14.11 .2019

Accepted: 18.12.2019

Mitochondrial dysfunctions (an impaired energy metabolism in the mitochondria) are essential in a pathogenesis of many diseases. Aim. The analysis of various mitochondrial dysfunction (MD) type study, as well as evaluation of drugs with an antihypoxic effect in their treatment. Methods. Collection, systematization and analysis of experimental and clinical data of current scientific research about the problem. Results. The mitochondrial dysfunctions can be caused by genetic disorders of the mitochondrial or nuclear genome (the primary MD or the mitochondrial diseases), as well as structural, functional and biochemical defects of mitochondria caused by other diseases (the secondary MD). MD are characterized by impaired tissue respiration, ATP synthesis deficiency and decreased energy metabolism. The clinical implications of $\mathrm{MD}$ are polysystemic and polymorphic. One of the biochemical sign of MD is the lactic acidosis. There are certain difficulties with the early diagnosis of primary MD. It is suggested to use complete exome sequencing among patients with a clinical suspicion on mitochondrial disease. The energotropic pharmacotherapy including drugs with an antihypoxic effect is used for MD treatment. It is more rational to use the drug combination that influences different stages of energy production. The combinations of L-carnitine, coenzyme Q10, cytochrome C and succinate-containing drugs are frequently used for MD. However, the usage of energotropic and antihypoxic drugs is not able to cure the patients and stop the progression of all disease displays. Conclusion. MD are a multidisciplinary problem, therefore, doctors of any speciality must be competent in the MD diagnosis and treatment. The use of energotropic agents in the MD treatment requires further research. Numerous issues remain open (daily drug doses choice, treatment duration, rational combinations). The phenotype variability and the uniqueness of diagnosed cases, clinical and genetic differences between patient groups with mitochondrial diseases fail to create homogeneous samplings for therapy effectiveness and safety analysis. The literature data are the results of different degrees of reliability. The international efforts are needed to unify studies of related mitochondrial disorders, which, in combination with a constant improvement of MD pathogenesis knowledge will allow to develop more effective treatment regimens.

- Keywords: mitochondria; mitochondrial dysfunctions; mitochondrial diseases; energotropic drugs; antihypoxants.

\section{МИТОХОНДРИАЛЬНЫЕ ДИСФУНКЦИИ И АНТИГИПОКСАНТЫ}

\author{
() В.Е. Новиков ${ }^{1}$, О.С. Левченкова ${ }^{1}$, Е.Н. Иванцова ${ }^{1}$, В.В. Воробьева ${ }^{2}$ \\ 1 ФГБОУ ВО «Смоленский государственный медицинский университет» Минздрава России, Смоленск; \\ 2 ФГБВОУ ВО «Военно-медицинская академия им. С.М. Кирова» Минобороны России, Санкт-Петербург
}

Для цитирования: Новиков В.Е., Левченкова О.С., Иванцова Е.Н., Воробьева В.В. Митохондриальные дисфункции и антигипоксанты // Обзоры по клинической фармакологии и лекарственной терапии. - 2019. - T. 17. - № 4. - C. 31-42. https://doi.org/10.7816/ RCF17431-42

Поступила: 02.10.2019

Одобрена: 14.11.2019

Принята: 18.12.2019

В патогенезе многих заболеваний существенное значение имеют митохондриальные дисфункции (нарушения энергообмена в митохондриях клеток). Цель работы - анализ изученности проблемы различных видов митохондриальных дисфункций (МД), а также оценка эффективности применения лекарственных препаратов с преимущественно антигипоксическим действием в их лечении. Методы. Сбор, систематизация и анализ экспериментальных и клинических данных современных научных исследований по соответствующей проблеме. Результаты. Митохондриальные дисфункции могут быть обусловлены генетическими нарушениями митохондриального или ядерного ге- нома (первичные МД или митохондриальные болезни), а также структурными, функциональными и биохимическими дефектами митохондрий на фоне других заболеваний (вторичные МД). Характеризуются МД нарушением тканевого дыхания, недостаточностью синтеза аденозинтрифосфата, снижением энергетического обмена. Клинические проявления МД полисистемны и полиморфны. Одним из биохимических признаков МД является лактатацидоз. Существуют определенные трудности с ранней диагностикой первичных МД. У пациентов с клиническим подозрением на митохондриальные болезни предлагается использовать полное секвенирование экзома. В лечении МД 
применяют энерготропную фармакотерапию, в том числе препараты с антигипоксическим действием. Более рационально использовать комбинацию препаратов, которые будут воздействовать на разные этапы процесса образования энергии. Наиболее часто при МД в комбинации используют такие препараты, как L-карнитин, Коэнзим Q10, Цитохром C, сукцинатсодержащие препараты. Однако использование энерготропных препаратов и средств с антигипоксическим действием не способно полностью излечить больного и купировать все проявления его заболевания. Заключение. МД являются междисциплинарной проблемой, поэтому врачи любой специальности должны быть компетентны в вопросах диагностики и терапии МД. Применение энерготропных средств в лечении МД требует дальнейшего изучения. Остаются открытыми многие вопросы (выбор суточных доз препара-

\section{INTRODUCTION}

The direction determining the significance and role of energy exchange disorders in mitochondria in the pathogenesis of diseases is developing actively in medical science over past decades. The conception "mitochondrial dysfunctions" (MD) is formed as a result of it [2, 4, 67].

The knowledge about mitochondria is being constantly supplementated and expanded [30, 42, 49, 51]. The diseases, based on hereditarily determined (primary) or acquired (secondary) mitochondrial dysfunction which was the disruption of energy production as ATP in the process of oxidative phosphorylation, have been detected $[17,26,36,38]$. MD are displayed by disorders of high energy-dependent nervous, cardiovascular and muscle systems.

Along with the mitochondria studies and the mitochondrial medicine formation the development and investigations of drugs restoring broken cell energy metabolism and increasing the organ and whole organism resistance to hypoxia are being carried out $[29,31,38$, $45,61]$. The hypoxic biochemical cascades develop exactly in ATP-producing mitochondria which can lead to cell death. In case of MD there is not only slowdown in the mitochondrial ATP synthesis, but the disorder of the entire metabolism in these organelles.

Nowadays the reasonableness of antihypoxant use in $M D$ is evident as the mechanism of the drug action is directly (for drugs with direct energizing effect) or indirectly (for drugs with indirect energizing action) connected with the disorder correction of the mitochondria work [23, 28, $65,72]$. That is why the antihypoxant use in MD is pathogenetically justified both for primary mitochondrial diseases and secondary mitochondrial dysfunctions. The differences are in the recommended doses, courses of application (in primary MD antihypoxants should be used for prolong time as replacement therapy, in secondary MD - from several weeks to several months). The combined use of antihypoxants with different mechanism of action is the most promising $[37,65]$. тов, продолжительность курса лечения, рациональные комбинации). При митохондриальных болезнях вариабельность фенотипов и единичность диагностируемых случаев, клинико-генетические различия групп пациентов не позволяют создать однородные выборки для анализа эффективности и безопасности терапии. Представленные в литературе данные являются результатами разной степени надежности. Необходимы международные усилия для унификации исследований, связанных с митохондриальными нарушениями, которые в сочетании с постоянным углублением знаний патогенеза МД позволят разработать более эффективные схемы их лечения.

Keywords: митохондрии; митохондриальные дисфункции; митохондриальные болезни; энерготропные средства; антигипоксанты.

This review is devoted to the evaluation of the drug effectiveness which commonly refer to antihypoxants in Russia as the treatment algorithms both for primary and secondary MD include energotropic drugs activating the transport of mitochondrial substrates, increasing ATP production and lowering the lactic acidosis level.

The aim is to analyze the current scientific literature data about different types of mitochondrial dysfunctions, to evaluate the drug effectiveness with mainly antihypoxic effect for the treatment of primary and secondary mitochondrial dysfunctions.

\section{MITOCHONDRIAL DYSFUNCTIONS}

Human mitochondria play a lot of functions. For example, they participate in the apoptosis, cell differentiation and proliferation, play one of the important roles in the aging. The estimation of the mitochondrial DNA (mtDNA) level in a blood is used to predict the complications and mortality in the malignant tumors [65]. However, the key function of mitochondria is the ATP formation in the biochemical cycles of cellular respiration. Mitochondria are the most important organelles of any cell in our body; a huge number of different biochemical processes like the carnitine cycle, the fatty acid oxidation, the tricarboxylic acid (Krebs) cycle, electron transport in the respiratory chain with mitochondrial enzyme complexes (MECs) and oxidative phosphorylation (OXPHOS) takes place in them [76]. That is why impaired mitochondrial functions are the most significant, and often the earliest stages of damage in various cellular structures. If not to stop it immediately it can lead to an insufficiency of cell energy supply, metabolic disorder and even to their total death [33,68].

The terms of "mitochondrial dysfunctions" and "mitochondrial diseases" in medical practice were formulated at the end of the twentieth century, when the diseases associated with mtDNA (deciphered in 1981) mutations have been studied. These are so-called primary 
mitochondrial dysfunctions or mitochondrial diseases. The frequency of hereditary diseases, the main pathogenetic and etiological factor of which are mitochondrial mutations, is $1: 5000$ people or more of the total population on our planet. MtDNA mutations are found in the human population more often, approximately $1: 3500$. But mtDNA mutations don't always lead to the mitochondrial diseases what is connected with the heteroplasmy level that is the proportion of normal (wild type) and abnormal (mutant) DNA molecules in the cell $[11,14]$. The number of mutant mtDNA can increase with age under various factor influence and gradually reach the level that can cause clinical displays of the disease [35].

Mutations in any mitochondrial genes encoding 13 main subunits of MECs and 22 mitochondrial transport RNAs and two ribosomal RNAs, as well as in any of the nuclear genes encoding the rest of the mitochondrial proteins, can lead to mitochondrial dysfunction and disease [74]. The most frequent mitochondrial diseases include MELAS syndrome (mitochondrial encephalomyopathy, lactic acidosis, stroke-like episodes), Kearns-Sayre syndrome (ptosis, ophthalmoplegia, bilateral retinopathy pigmentosa, heart block), MERRF syndrome (myoclonic epilepsy with ragged red fibers), Leber's hereditary optic neuropathy (LHON), NARP syndrome (neuropathy, ataxia and retinitis pigmentosa), etc. [69, 75].

Mitochondrial dysfunctions and related diseases can be assotiated with the cell nucleus genome damage nDNA [55]. They are less studied than MD caused by mtDNA mutations and include various forms of infantile myopathies, Leigh syndrome (subacute necrotizing encephalomyopathy), Barth syndrome (cardiomyopathy, myopathy, stunting) $[3,59,74]$. In the absence of other reasons of the neuropsychic and physical development retardation, intolerance to physical activity and muscle weakness in children we should think about differential diagnosis with mitochondrial diseases.

Most mitochondrial diseases are characterized by the progressive nature and lead to disability and mortality. They can develop at any age, about $30 \%$ of cases manifest in the neonatal period and they are maternally inherited [12]. Primary mitochondrial dysfunctions are manifested mainly by the central and peripheral nervous, muscular and cardiovascular system disorders, i. e. those systems and tissues which cells are the richest in mitochondria number. Their main symptoms are muscle weakness, intolerance to physical exertion, retardation in neuropsychic development, declined growth, in some cases muscle pain, vomiting, cramps, stroke-like episodes, hearing loss, ptosis and ophthalmoplegia $[18,37,65]$.

Secondary mitochondrial dysfunctions can be observed in various acquired diseases, for example, in acute coronary syndrome, cardiomyopathy, some forms of progressive muscular dystrophies, connective tissue diseases, as well as in a number of pathological conditions in which hypoxia plays a key role $[58,61]$. In these diseases, disorders of cellular energy exchange act as "secondary" links of pathogenesis. Besides, secondary
MD can be caused by carbon monoxide poisoning, cyanides, heavy metal salts, prolonged use of high doses of azidothymidine, valproates, aminoglycosides and group B vitamin deficiency [65]. The clinical manifestations of secondary MD are observed in the same mitochondria-rich organ and tissue as in primary MD.

Mitochondrial disease pathogenesis has been studied well enough by now. It can be presented in stages as follows: substrate transport, their oxidation, tricarboxylic acid (TCA) cycle, respiratory chain (electron transport chain) functioning, the coupling of tissue respiration and OXPHOS. The glucose oxidation to pyruvate occurs with the participation of the pyruvate dehydrogenase complex enzymes with the formation of acetylCoA, which is included in the TCA cycle. The fatty acid utilization occurs in the $\beta$-oxidation process. Electrons formed during these reactions are transported into the respiratory chain. The latter is formed by 5 multienzyme complexes, 4 of which carry out electron transport, and the fifth catalyzes ATP synthesis. The subunits of the respiratory chain complexes are under double control of the nuclear and mitochondrial genomes (see Fig.). From the position of pathogenesis 3 main categories of mitochondrial diseases can be named: 1 ) diseases of OXPHOS, 2) diseases of $\beta$-oxidation of fatty acids, 3 ) defects in the metabolism of pyruvate and the TCA cycle $[45,65,76]$.

The calcium homeostasis is impaired in MD. The observed calcium excess contributes to the mitochondria overload and thereby reduces ATP molecules formation and increases the production of reactive oxygen species (ROS) [41, 43, 50], what finally increase the apoptosis and necrosis risk. There is a direct correlation between a person's age and the activity of his mitochondrial structures. The older the person is, the more serious is the energy exchange weakening due to decrease in the function of ATP-producing organelles, what partly explains the development of Alzheimer's disease, Parkinson's disease, autism, ischemic heart disease, diabetes mellitus type 2 and etc. [56, 69-71].

The diagnosis of MD (especially primary) is quite difficult and requires special genetic studies [59]. As screening diagnostic sign of MD it's possible to use the determination of increased lactate concentration (more than $2.2 \mathrm{mmol} / \mathrm{l}$ ) and pyruvate (more than $0.12 \mathrm{mmol} / \mathrm{l}$ ) in the blood and liquor, as well as their ratio in the peripheral blood (more than 20) [24, 27]. It is more informative to measure the level of lactate in venous blood after (in half an hour) moderate exercise or the load by easily digestible carbohydrates [24]. The spectrum of amino acids and acylcarnitines in the blood are determined as well. Urinary excretion of organic acids is investigated by gas chromatography with mass spectrometric detection (the increased level of lactate, pyruvate, fumarate, succinate and etc. can be found). The level of FAc and lipid peroxidation products increases in the blood $[14,65]$. The rise of myoglobin level, $\beta$-hydroxymethylene, acetoacetic acid and ammonia in the blood may also be typical for MD. The informative value of the increased 


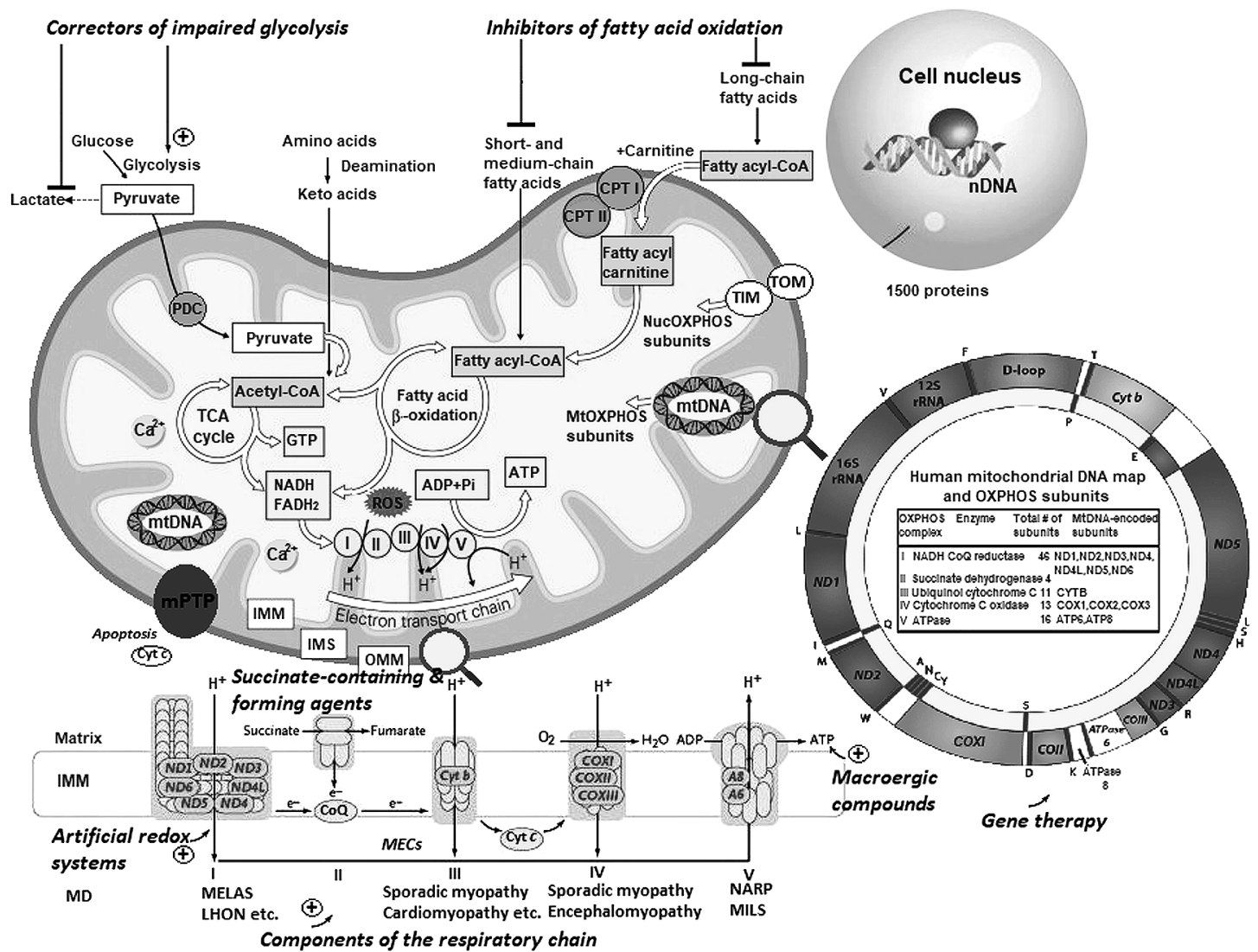

Fig. Possible localization of mitochondrial dysfunctions and places of antihypoxant action. ATP - adenosine triphosphate; CPT I - carnitine palmitoyltransferase I; CPT II - carnitine palmitoyltransferase II; GTP - guanosine triphosphate; IMM - inner mitochondrial membrane; IMS - intermembrane space; MECs - mitochondrial enzyme complexes; mPTP mitochondrial permeability transition pore; mtDNA - mitochondrial DNA; nDNA - nuclear DNA; OMM - outer mitochondrial membrane; OXPHOS - oxidative phosphorylation; PDC - pyruvate dehydrogenase complex; ROS - reactive oxygen species; TIM - translocase of the inner membrane; TOM - translocase of the outer membrane; ADP - adenosine diphosphate; NADH - nicotine-adenine dinucleotide recovered; FADH - flavine adenine dinucleotide recovered; TCA tricarbonic acids cycle; NARP - neuropathy, ataxia and retinitis pigmentosa syndrome

concentration in plasma of fibroblast growth factor-21 (FGF-21) and especially the growth factor-15 (GDF-15) is shown by enzyme immunoassay $[12,24]$. It is possible to conduct cytochemical analysis to determine mitochondrial enzymes (for example, decrease of succinate dehydrogenase, citrate synthetase and cytochrome C synthetase level) in peripheral blood lymphocytes and punctates of some organs, in the urine sediment. Typical changes can be detected in magnetic resonance imaging (MRI) of patient brain with MD, for example, symmetrical damage of the subcortical nuclei in the form of cystic changes, foci in the temporal and occipital areas and etc. [12, 35, 75].

In primary MD, the main histological (morphological), enzymatic and functional criteria are: 1) raggedred fibers (RRF) in the muscles in an amount more than $2 \%$ (biopsy of skeletal muscles, usually quadriceps or deltoid, is performed); 2) the presence of cytochrome oxidase-negative fibers; 3 ) the decrease of the respiratory chain complex activity $<20-30 \%$ of the norm; 4 ) determination of succinate dehydrogenase in peripheral lymphocytes; 5) subsarcolemmal accumulation of glycogen, lipids, calcium ions (the accumulation of fat drops in various tissues, including muscle fibers, occurs as a result of impaired oxidation of $\mathrm{FAc}$ ) $[37,65]$.

The molecular genetic test by the mitochondrial genome sequencing (it is possible to use a dried drop of blood on a filter paper) can determine if patient has a genetic mutation that causes the development of MD. The genetic test allows to detect the appearance of mitochondrial mutations with a high ratio of abnormal and normal mitochondrial DNA [14]. The absence of mitochondrial mutation suggests that the patient has the pathology associated with a nuclear DNA mutation.

\section{THERAPY FOR MITOCHONDRIAL DYSFUNCTIONS}

Nowadays the primary MD are incurable but it is possible to slow down the progression of the disease, to compensate the patient condition. Mitochondrial diseases are rare orphan diseases, the treatment regimen for which is chosen individually. Today, the complex treatment of primary MD is carried out and it includes the following components. 
Pharmacotherapy, which consists mainly of the drugs with metabolic type of action (energotropic): drugs with antihypoxic effect (coenzyme Q10 - 2-20 mg/kg/day; cytochrome C - 30-60 mg/day; succinic acid preparations - $8-10 \mathrm{mg} / \mathrm{kg} /$ day, L-carnitine $-20-100 \mathrm{mg} / \mathrm{kg} / \mathrm{day}$, mexidol, etc.) $[3,6]$; nootropics (idebenone, choline alfoscerate) $[12,54]$; antioxidants ( $\mathrm{N}$-acetylcysteine, mitochondria-targeted antioxidants based on plastoquinol under the SkQ code, elamipretide [25, 64]; vitamin and vitamin-like preparations (vitamin $\mathrm{E}$ preparations 50-300 mg/day; C - 500-1000 mg/day; PP - 20$30 \mathrm{mg} /$ day; $\mathrm{B}_{1}-20-100 \mathrm{mg} /$ day; $\mathrm{B}_{2}-100-400 \mathrm{mg} /$ day; $\mathrm{H}-5 \mathrm{mg} /$ day, in severe cases up to $30 \mathrm{mg} /$ day; lipoic acid - 50-200 mg/day) [6]; drugs that reduce the degree of lactic acidosis (dimephosphon $30 \mathrm{mg} / \mathrm{kg}$, L-arginine). It should be noted that many drugs produce several and sometimes all of the above enumerated effects. The pharmacotherapy efficacy may vary in patients even with the same molecular genetic defect.

Rational diet therapy (usually, ketogenic diet) with a reduced amount of easily digestible carbohydrates, high fat content and average protein content in combination with exercise therapy is recommended to be used $[2,65]$.

Genetic counseling minimizes the inheritance risk of a pathogenic mitochondrial mutation [11].

Palliative therapy includes a psychological help, the use of symptomatic therapy, in particular antiepileptic drugs (levetiracetam, topiramate, oxcarbazepine, at the same time, valproate and phenobarbital-containing agents are contraindicated, as they inhibit the work of mitochondrial enzyme complexes), hemodialysis, ALV $[16,25,60]$.

Gene therapy is used to suppress mutations in the mitochondrial genome (at the stage of experimental studies mainly on human cell cultures). The possibility of mitochondrial replacement therapy in 5 main areas is studied: 1 - xenotopic gene expression; 2 - allotopic gene expression [25]; 3 - the synthesis of artificially created in vivo mitochondrial tRNA and rRNA with their subsequent transfer to mutant mitochondria with damaged structures replacement; 4 - the creation of "vector" nucleic acids complementary to the mutated piece of mtDNA, which while binding to them, contribute to their inhibition and shutdown of the replication processes; 5 - the use of artificially created vesicles penetrating through the membranes of mitochondria and restoring lost functions. Besides, the mutation correction systems in mtDNA based on molecular genome editing technologies, for example, systems called "mitochondrial zinc fingers", mitoTALEN, mitoCRISPR/Cas9 are being developed $[2,11]$. The main disadvantage of these directions is that they do not eliminate the underlying mutation in the mitochondria genome, but only reduce the heteroplasmy level, resulting in partial restoration of the mitochondria function.

In secondary mitochondrial dysfunction the pharmacotherapy by energotropic and antihypoxic agents is mainly used $[38,65]$.

\section{ANTIHYPOXANTS IN MITOCHONDRIAL DYSFUNCTIONS TREATMENT}

We used the antihypoxant classification to estimate their effectiveness in mitochondrial dysfunctions consistently. According to the classification there are five main groups of antihypoxants: inhibitors of fatty acid oxidation and correctors of impaired glycolysis effectiveness; succinate-containing and succinate-forming agents; natural components of the respiratory chain; artificial redox systems; macroergic compounds [28, 40, 45].

Inhibitors of fatty acid oxidation (FAO). There are 3 subgroups: direct carnitine palmitoyl transferase-1 (CPT1) inhibitors (perhexelin, etomoxir), partial fatty acid oxidation inhibitors (so called pFOX inhibitors) (trimetazidine, ranolazine, meldonium) and indirect FAO inhibitors (carnitine). Inhibitors of CPT1 with irreversible action are practically not used for mitochondrial disorders due to their neuro- and hepatotoxicity [45].

Trimetazidine (preductal) blocks 3 ketoacyl-CoA thiolase, which slows down the intramitochondrial oxidation of both long-chain and short-chain FAs; the number of intramitochondrial active FAs remains unchanged [71]. Trimetazidine increases the pyruvate oxidation. IntracelIular lactic acidosis is decreased as a result, the overload of calcium ions is eliminated, and the glycolytic production of ATP increases [45]. Free FAs that are not utilized in the $\beta$-oxidation go for membrane phospholipid synthesis. Besides trimetazidine increases the activity of antioxidant enzymes indirectly, inhibiting an oxidative stress [29]. The effectiveness of trimetazidine for primary MD has not been found, for secondary MD is disputable [57, 64, 71]. On the one hand, the clinical efficacy of trimetazidine is confirmed by randomized trials, which have demonstrated its cardioprotective action in coronary heart disease, chronic heart failure $[13,64]$. However, in the work of M. Cavar et al. which was devoted to trimetazidine influence on FAO (palmitoylcarnitine) and carbohydrate (pyruvate) oxidation directly in the left ventricular myocardium (fibers obtained from patients with stable angina during coronary artery bypass grafting), the known mechanism of its action was not confirmed. So, there were no differences between the experimental group (receiving trimetazidine before surgery for 30 days in a daily dose of $70 \mathrm{mg}$ ) and the control group (not receiving trimetazidine) in the oxidation of palmitoylcarnitine or pyruvate, as well as in the ratio of carbohydrate and FA oxidation. The activity and expression of pyruvate dehydrogenase also did not differ statistically between groups. Direct applying of different trimetazidine concentrations on myocardial tissue in vitro did not affect the oxidation of FAs in the myocardium [10].

In addition trimetazidine showed equal ability to increase ( $48 \%$ of patients) and decrease (52\%) the functional activity of leukocyte mitochondria in patients with stable exertional angina, which needs to personalize trimetazidine use in the complex therapy of patients with MD. The individual state of target organs (liver and 
kidneys), the ratio of cortisol/insulin and cAMP/cGMP in serum, the initial activity of mitochondria should be taken into account [57].

The antihypoxic effect of ranolazine (ranex) is due to decrease of free FAs use as an energy source/substrate and increase of glucose use in the main energy metabolism reactions [29, 45]. Ranolazine is most often used as a part of combined therapy for secondary MD associated with coronary heart disease, since it not only rises the ATP formation, but also has antianginal activity [45]. However, randomized controlled trials are required to confirm the protective role of ranolazine for MD treatment in heart failure [64]. Information about the use of ranolazine for primary MD is not found in literature database.

Meldonium (mildronate) is used for primary and secondary MD. The main mechanism of its action is the reversible inhibition of the rate of carnitine synthesis from its precursor $-\gamma$-butyrobetaine, which leads to decrease of carnitine-mediated transport of long-chain FAc without changing the metabolic processes of short-chain FAc through mitochondrial membranes, i. e. there is no a complete block in all FA oxidation [29, 45]. Therefore the use of meldonium for primary MD treatment, in particular MELAS syndrome, is justified, especially for arrest of its manifestation - cardiomyopathy [52]. The neuroprotective effect of meldonium was demonstrated in the complex treatment of acute ischemic stroke in secondary MD [63]. As a component of the complex therapy after acute period of cerebrovascular disease (stroke, transient ischemic attack) in patients suffering from dyscirculatory encephalopathy with cognitive impairment meldonium improved significantly their condition (1000 mg/day for 10 days in infusion form followed by oral administration in the same daily dose for 3 months) [21].

Carnitine ( $L$-carnitine, elkar) is an endogenous compound formed in kidneys and liver from methionine and lysine, plays an important role in the regulation of acetylCoA (regulates the transfer of long-chain FAs through mitochondrial membranes with their subsequent betaoxidation and the formation of acetyl-CoA molecules). Carnitine stabilizes the activity of enzymatic systems involved in ATP formation in hypoxia condition with relative mitochondrial insufficiency. Besides, it changes the process of ATP formation from anaerobic glucose oxidation to aerobic, thereby reducing the amount and rate of the lactate formation. Furthermore it inhibits the formation of peroxidation products in the mitochondria $[4,29,45]$.

Carnitine in physiological concentrations contributes to the saturation of palmitoiltransferase I (has a specific vitamin effect), in higher doses it speeds the enzymatic transfer of acyl groups of FAs through the mitochondrial membrane. Carnitine leads to the activation of carnitine-acylcarnitines and reduce of intramitochondrial acetyl-CoA. The decrease of acetyl-CoA in mitochondria triggers a series of cascade reactions aimed at increasing of the pyruvate dehydrogenase concentration, providing pyruvate oxidation and limiting the lactate formation. Thus, carnitine should be taken in doses exceeding its physiological value to produce antihypoxic action [45].

There is a lot of literature data about L-carnitine use in various mitochondrial diseases. But the results of its effectiveness are contradictory [37]. The use of L-carnitine in placebo-controlled trials for patients with MELAS syndrome in dose 4-10 g/day caused decrease in muscle weakness and lactate level after physical exertion [22, 27]. However, L-carnitine use in Kearns-Sayre syndrome ( $150 \mathrm{mg} / \mathrm{kg}$ for 6 weeks) didn't cause reliable changes in the patient condition [27].

Carnitine effectiveness in secondary $\mathrm{MD}$ in mitral valve prolapse (without regurgitation) in children is shown. The use of the drug in the age dosage (from 7 to 12 years $0.3 \mathrm{~g}$, from 12 to 14 years $0.5 \mathrm{~g}$ ) 2 times per day for 12 months in combination with the drug ubiquinone contributed to a significant increase of methionine, ornithine, glutamine and other amino acid level in blood, as well as free and bound carnitine [5].

Correctors of impaired glycolysis effectiveness include metaprot (bemitil) and thiotriazolin. The mechanism of metaprot action is based on the activation of the synthesis of gluconeogenesis enzyme complexes, which contribute to reduce the lactic acidosis and to enhance the glucose resynthesis. The antihypoxic activity of metaprot is due to the increased synthesis of mitochondrial enzymes and structural proteins, which provides a high level of ATP synthesis even in hypoxia. Metaprot supports the work of the NAD- and FAD-dependent enzymes of the respiratory chain, reduces the uncoupling of oxidation with phosphorylation. There is data about metaprot effectiveness in secondary MD in case of traumatic brain injury, acute and chronic cerebrovascular accident [28, 61]. Its effectiveness in combination with cytochrome $\mathrm{C}$ and physiotherapy in the treatment of hereditary neuromuscular diseases has been demonstrated.

Thiotriazoline normalizes oxidative processes in the TCA cycle, increases the intracellular ATP content. It helps in the glucose utilization by the cell in ischemia tissue. Thiotriazoline increases the activity of cytochrome-C-oxidase, enhances the level of pyruvate, malate, isocitrate, succinate. At the same time it reduces the formation of lactate eliminating the lactate-acidosis. Thiotriazoline influences the opening of the cyclosporine-A-dependent pore, saves the mitochondrial membrane charge, increases the level of heat shock protein HSP70 in the mitochondria. The use of thiotriazoline in clinic practice demonstrated its effectiveness in secondary MD, where it improved the quality and life expectancy of patients with myocardial infarction, chronic heart failure, after myocardial remodeling [9]. Thiotriazoline is indicated in the complex therapy of MELAS syndrome in cardiomyopathy, as well as in the therapy of the metabolic stroke [18].

Succinate-containing and succinate-forming agents contribute to the maintenance of the succinate oxidase (FAD-dependent part) of the TCA cycle. The succinate 
oxidase unit under hypoxia and in succinate (succinic acid) presence in the mitochondria is able to compensate the energy exchange processes and maintain the ATP level at the required level. Succinate produces antihypoxic effect by two ways. Firstly, it acts as a substrate of the TCA cycle and the enzyme succinate dehydrogenase (SDH, MEC II). Secondly, it plays a role of a signaling molecule, activates HIF- $1 \alpha$ and the orphan receptors SUCNR1 and GPR91. Interaction with the latter promotes increase of reabsorbed glucose level and gluconeogenesis stimulation [31, 45, 62].

The possibility of succinic acid drug use in mitochondrial dysfunction has recently been discussing in the scientific literature. The case was described when the succinate use in the patient with MELAS syndrome $(6 \mathrm{~g} /$ day, 3 month course) led to the complete disappearance of all neurological symptoms [65]. The efficacy of the succinate-containing drug in secondary MD conditions was shown (cardioprotective properties were demonstrated on the hypoxic type vibrational model of cellular metabolism) [72]. Combined succinate-containing drugs such as reamberin, cytoflavin, remaxol have found indications in clinical practice for patients with MD.

Reamberin is the polyionic solution (contains $\mathrm{NaCl}$, $\mathrm{KCl}, \mathrm{MgCl}_{2}$ ), the main component of which is sodium $\mathrm{N}$-methylglucamine salt of succinic acid [29]. Reamberin infusions are indicated in conditions characterized by secondary MD, such as ischemic and hemorrhagic stroke, coronary artery bypass grafting, direct myocardial revascularization [45]. It is recommended to use as a metabolic modulator of microcirculatory-mitochondrial dysfunction in various critical conditions with multiple organ dysfunction syndrome [68]. It is not possible to estimate the effectiveness of reamberin in primary MD due to insufficient clinical observations. Its use in the complex treatment of mtDNA depletion syndrome due to mutations in the FBXL4 gene is described [12].

Cytoflavin contains succinate, nicotinamide, riboflavin mononucleotide and inosine. The components of cytoflavin potentiate the antihypoxic effect of succinate. So, riboflavin increases the activity of succinate dehydrogenase, inosine increases the total number of purine nucleotides necessary for the ATP and GTP resynthesis. Currently, the effectiveness of cytoflavin in the complex treatment of Leigh syndrome and stroke, discirculatory encephalopathy, perinatal hypoxic-ischemic brain injury, characterized by secondary MD has been discussed $[45,59]$.

Remaxol is the succinate-containing drug for intravenous infusion that combines the components of reamberin and cytoflavin. Its antihypoxic and antioxidant effect was shown in secondary MD associated with liver damage of different etiologies [45].

Ethylmethylhydroxypyridine succinate (mexidol, mexicor) is widely used today in Russia as the succinatecontaining drug. It activates a compensatory metabolic process due to the succinate entrance in the respiratory chain, energysynthesizing mitochondrial function, improves the energy metabolism, maintains the macroer- gic compound level in mitochondria insufficiency. Mexidol inhibits lipid peroxidation, increases the activity of antioxidant enzymes - superoxide dismutase and glutathione peroxidase due to 3-hydroxypyridine component. Mexidol modulates the functioning of membrane-bound enzymes (adenylate cyclase, acetylcholinesterase, etc.), transport systems of neuromediators, ion channels, receptors and receptor complexes (acetylcholine, GABA, etc.), is able to reduce the glutamate excitotoxicity and NO level $[48,73]$.

Mexidol is used mainly for secondary MD in neurodegenerative diseases, acute and chronic cerebrovascular accidents, traumatic brain injury, heart failure [1, 44, 73]. However, despite the experimental and clinical advantages of mexidol over other succinate-containing drugs, ethylmethylhydroxypyridine succinate is not included in the international guidelines for the treatment of cerebrovascular accidents due to methodological reasons (small patient samples in clinical trials, the inclusion and exclusion criteria, etc.) [15].

As for primary MD mexidol was used as part of the complex therapy of MELAS syndrome during the period of acute manifestations [18]. Positive dynamics was noted with help of mexidol in mitochondrial myopathy [77].

There are drugs that can turn into succinate (succinate-forming) in the body. These include sodium fumarate (confumin) and the combined drugs like mafusol and polyoxyfumarin (colloidal crystalloid solutions for intravenous use containing sodium fumarate). The flow of many final reactions of the TCA cycle changes in MD. The advantage of fumarate-based agents in MD is that fumarate easily penetrates through cell membranes and turns into succinate [45].

These drugs are recommended for secondary MD developed in hypovolemic and hypoxic conditions of various etiologies (blood loss, including severe gastroduodenal bleeding, hemorrhagic shock, etc.), as a component of the perfusion system to fill the cardiopulmonary bypass. The renoprotective effect was observed in the experiment with ischemia-reperfusion of the kidneys, when the preventive course of sodium fumarate $(1.5 \mathrm{ml} / \mathrm{kg}$ intravenously 24 and 2 hours before surgery) contributed to limit the kidney tissue damage in hypoxia [47].

Natural components of the respiratory chain. This group of drugs includes coenzyme Q10 (ubiquinone) and cytochrome $C$. They are mainly used as replacement therapy in MD, because in mitochondrial injuries, the latter lose some of the important structural components, including the electron carriers.

Coenzyme Q10 (ubiquinone) is an endogenous substance that is part of many cellular structures, including mitochondria and Golgi apparatus. The main function of ubiquinone is the transfer of protons and electrons from the inner surface of the mitochondrial membrane to the outer one (from MEC I and II to complex III), thereby taking part in the ATP formation. It is part of the respiratory chain, it is able to play the role of an antioxidant in hypoxia conditions $[28,40]$. 
The deficiency of ubiquinone and disorder of the IId and IIIrd MEC activity under hypoxia can be manifested in the form of Kearns-Sayre syndromes, MILS, MERRF and MELAS. Exogenous coenzyme Q10 is able to eliminate the initial causes of the above syndromes, therefore, its use in MD is justified [4, 65]. Coenzyme Q10 is frequently used drug for treatment of mitochondrial diseases. Its effectiveness is manifested in daily dose 300-1500 mg. The positive result from coenzyme Q10 taking was proved during the placebo-controlled study in patients with MELAS syndrome and progressive ophthalmoplegia [37, 46]. The usefulness of coenzyme Q10 4 month course as a part of the combined energotropic therapy in children with early signs of autism has been noted [65].

The effectiveness of coenzyme Q10 in secondary MD has been shown in experimental and clinical studies. So, its cardioprotective and neuroprotective activity was shown in experimental models of chronic myocardial ischemia and chronic brain ischemia [8]. The protective effect was observed with coenzyme Q10 use in patients with the chronic heart failure and in conditions accompanied by ischemia-reperfusion [34]. Water-soluble formulations of ubiquinol-10 are recommended to increase coenzyme Q10 absorption and bioavailability both in primary and secondary MD [20].

Idebenone (noben) is the synthetic derivative of ubiquinone, in comparison with coenzyme Q10 it has 5 times smaller size, less hydrophobicity. Idebenone is characterized by marked antioxidant and nootropic effect [54]. The effectiveness of idebenone in the complex therapy of MD such as MELAS syndrome, Leber optic atrophy, Lei's disease has been demonstrated [4].

Cytochrome $C$ (cytomac) is also the component of the respiratory chain. Exogenous cytochrome $\mathrm{C}$ penetrates the outer mitochondrial membrane, integrates into the respiratory chain and normalizes the energy production by OXPHOS stabilizing in hypoxia condition [23]. The use of cytochrome $\mathrm{C}$ in children with KearnsSayre syndrome contributed to decrease of the lactate level in the blood and clinical symptoms of the disease, but with its further use (more than 3 years), the patients showed a slow progression of the disease (impaired contractility of the myocardium and cardiac conduction system) [37, 65]. As for secondary MD the use of cytochrome $\mathrm{C}$ improved the myocardial functional state and systemic hemodynamics in patients with myocardial infarction, ischemic heart disease complicated by arrhythmias and/or chronic heart failure [23]. Besides, cytochrome $\mathrm{C}$ is prescribed for asphyxia in newborn, in the postoperative period after heart surgery.

Artificial redox systems. The pharmacodynamics of these drugs is to compensate for the oxygen deficiency as the main electron acceptor. The overload of the respiratory chains by electrons, which inhibits the cellular and tissue respiration and, as a result, reduces the phosphorylation rate, is observed in hypoxia. To eliminate this defect, it is possible to use drugs of artificial redox systems that remove excess electrons of the respira- tory chains by shunting their main links. Besides, the drugs stop the lactate excess arising in secondary MD, especially during physical exertion, since they provide the cytosolic oxidation of $\mathrm{NADH}$, which prevents the glycolysis inhibition and thereby limits the accumulation of excess lactate [29, 40].

Sodium polydihydroxyphenylene thiosulfonate (hypoxene, oliphene) belongs to artificial redox system. Hypoxene is able to bypass electron transport flows (MECs I and III) along the mitochondrial respiratory chain due to its polyphenolic quinone structure. Besides, hypoxene contributes to faster oxidation of accumulated $\mathrm{NADPH}$, FADH2 in posthypoxic condition [30, 45]. There is efficient to include hypoxene in the treatment of secondary MD with ischemic heart disease, chronic obstructive pulmonary disease, toxic liver damage $[39,45]$. The use of hypoxene in patients with myocardial infarction eliminated ventricular fibrillation, reduced the mortality rate in acute period. Besides, hypoxene improved the clinical course of the perioperative period after revascularization in patients with coronary bypass operations.

Macroergic compounds. The possibility issue of this drug usage in primary and secondary MD remains open $[65,66]$. The use of creatine phosphate and drugs based on it is criticized due to the fact that they undergo dephosphorylation rather quickly and disintegrate in tissues [3].

At the same time the cases of creatine monohydrate successful use are described. Its use in acute coronary syndrome, ischemic heart disease led to stabilization of the damaged cardiomyocyte membranes, maintaining their contractile activity at optimum level, prevented the development of hypoxic contractures in the heart and reduced platelet aggregation [45]. The effectiveness of creatine monohydrate is shown in patients with MELAS syndrome, mitochondrial myopathy and necrotizing encephalomyopathy (Leigh syndrome) in children $[7,66]$. Other studies (including use in Kearns-Sayre syndrome) did not reveal the clinical efficacy of creatine monohydrate [65].

\section{CONCLUSION}

Mitochondrial dysfunctions are a heterogeneous group of disorders affecting tissue respiration, ATP synthesis and energy metabolism. MD can be genetic primary MD or mitochondrial diseases, as well result of other diseases - secondary MD. Clinical manifestations of MD are polysystemic and polymorphic, can be of different severity. MD are an interdisciplinary problem, therefore, doctors of any specialty should know main biochemical processes in the patient body at the cellular level, and be competent in the diagnosis and general principles of MD treatment. One of the possible MD biomarker is lactic acidosis. But there are certain difficulties with the early diagnosis of primary MD [24, 32].

It is not always possible to identify a pathogenic variant even with a molecular genetic study of mtDNA. 
Therefore, it is proposed to use complete exome sequencing for patients with a clinical suspicion on mitochondrial disease (in children with any multisystem, neurological and/or neuromuscular problems) [60]. Variants of nuclear DNA disorders in children with MD are more common than mtDNA [53].

Nowadays the use of energotropic drugs, in particular, drugs with antihypoxic action is one of the most important ways to fight against the mitochondrial disorders. Researchers interpret the pharmacotherapeutic approach to the MD treatment with antihypoxants by different manner. Some consider the antihypoxant use in $\mathrm{MD}$ as pathogenetic therapy, others - as replacement or symptomatic $[19,65]$. In any case, the problem of hypoxia, which is present in MD, cannot be solved without energy substrates capable to return the oxidation processes in the cell to the usual aerobic pathway.

The use of energotropic drugs for the treatment of primary and secondary MD is not always effective. Moreover, it is not always possible to identify the specific location of the damage and the mechanism of mitochondrial disorder development. Therefore it is more rational to use a combination of drugs that influence on several of the most important stages of the energy generation process. The effectiveness of the complex pharmacotherapy with antihypoxants is shown for primary MD. More often drugs as L-carnitine, coenzyme Q10, cytochrome $\mathrm{C}$ and succinate-containing drugs are used in mitochondrial diseases [46]. However, the use of different combinations of energotropic and antihypoxic drugs is not able to cure the patient completely and stop all manifestations of the disease. Moreover, patient state may worsen with the progression of symptoms of the disease (Kearns-Sayre syndrome) in prolonged use of energotropic therapy (coenzyme Q10, cytochrome C, arginine, etc.).

Thus, the problem of treatment of patients with different types of mitochondrial dysfunctions with energotropic drugs requires further study. Many questions remain open (choice of daily doses of drugs, duration of treatment, rational combinations). For example, for succinate-containing preparations and carnitine, which can realize their effect in small doses through activation of adaptation signaling pathways, the question of the optimal dose choice is relevant. Obviously, it is necessary to use the complex therapy with an individual choice of antihypoxants and other energotropic drugs in the optimal drug form, sufficient dose and duration of use for marked effect and faster results.

The reliable effectiveness evaluation of antihypoxant drugs and their combinations in MD is difficult, because sometimes it is impossible to compare data. The variability of phenotypes and the uniqueness of diagnosed cases, the rarity of some forms, the clinical and genetic differences between groups of patients receiving therapy fail to form a homogeneous patient samples for analysis of the therapy effectiveness and safety. Comparative evaluation of effectiveness is generally difficult due to the absence of unified criteria for estimation of the disease dynamics (like muscle strength, episodic seizures, vomiting, etc.) and, as a consequence, the effectiveness of pharmacotherapy [19]. Therefore, there are currently few results of eligible randomized clinical trials. The data presented in the literature are the results of varying degrees of reliability. Rational antihypoxic therapy regimens should be based on the results of controlled clinical trials. The international efforts are necessary to unify studies related to mitochondrial disorders, which, combined with the constant supplementation of MD pathogenesis knowledge will allow to use more effective treatment regimens.

\section{REFERENCES}

1. Abramenko YV. The efficacy of mexidol for transient ischemic attacks in the vertebrobasilar system in elderly patients with chronic cerebral ischemia. Zh Nevrol Psikhiatr im S.S. Korsakova. 2018;118(9-2):42-48. (In Russ.)] https://doi.org/10.17116/jnevro201811809242.

2. Ahmed ST, Craven L, Russell OM, et al. Diagnosis and Treatment of Mitochondrial Myopathies. Neurotherapeutics. 2018;15(4):943-953. https://doi.org/10.1007/s13311-01800674-4.

3. Ahuja AS. Understanding mitochondrial myopathies: a review. PeerJ. 2018;6:e4790. https://doi.org/10.7717/ peerj. 4790 .

4. Avula S, Parikh S, Demarest S, et al. Treatment of mitochondrial disorders. Curr Treat Options Neurol. 2014;16(6):292. https://doi.org/10.1007/s11940-014-0292-7.

5. Baedilova MT, Sumenko VV, Sukhorukov VS, et al. Efficiency of energy-rich therapy for cellular energy metabolic disturbances in children with mitral valve prolapse. Rossiyskiy Vestnik Perinatologii i Pediatrii (Russian Bulletin of Perinatology and Pediatrics). 2017;62(1):74-80. https:// doi.org/10.21508/1027-4065-2017-62-1-74-80.

6. Baranov AA. Pediatrics: national guidelines. Moscow: GEOTAR-Media; 2009. (In Russ.)

7. Barbieri E, Guescini M, Calcabrini C, et al. Creatine Prevents the Structural and Functional Damage to Mitochondria in Myogenic, Oxidatively Stressed C2C12 Cells and Restores Their Differentiation Capacity. Oxid Med Cell Longev. 2016;2016:5152029. https://doi. org/10.1155/2016/5152029.

8. Belousova M, Tokareva OG, Gorodetskaya E, et al. Intravenous Treatment With Coenzyme Q10 Improves Neuological Outcome and Reduces Infarct Volume After Transient Focal Brain Ischemia in Rats. J Cardiovasc Pharmacol. 2016;67(2):103-109. https://doi.org/10.1097/ fjc. 0000000000000320 .

9. Bielenichev IF, Vizir VA, Mamchur VY, Kuriata OV. Place of tiotriazoline in the gallery of modern metabolitotropic medicines. Zaporozhye Medical Journal. 2019;0(1). https://doi.org/10.14739/2310-1210.2019.1.155856.

10. Cavar M, Ljubkovic M, Bulat C, et al. Trimetazidine does not alter metabolic substrate oxidation in cardiac mitochondria of target patient population. Br J Pharmacol. 2016;173(9): 1529-1540. https://doi.org/10.1111/bph.13454. 
11. Chicherin IV, Levitskii SA, Krasheninnikov IA, et al. The prospects of gene therapy for mitochondrial diseases: can't we do without CRISPR/Cas9? Bulletin of Russian State Medical University. 2017(3):43-47. https://doi. org/10.24075/brsmu.2017-03-05.

12. Degtyareva AV, Stepanova EV, Itkis YS, et al. Clinical case of Mitochondrial DNA Depletion. Rossiyskiy Vestnik Perinatologii i Pediatrii (Russian Bulletin of Perinatology and Pediatrics). 2017;62(5):55-62. https://doi. org/10.21508/1027-4065-2017-62-5-55-62.

13. Dézsi CA. Trimetazidine in Practice. Am J Ther. 2016;23(3): e871-e879. https://doi.org/10.1097/mjt.0000000000000180.

14. Dimmock DP, Lawlor MW. Presentation and Diagnostic Evaluation of Mitochondrial Disease. Pediatr Clin North Am. 2017;64(1):161-171. https://doi.org/10.1016/j.pcl.2016. 08.011 .

15. Ehrlikh AD, Gratsianskii NA. Evidence Base of Ethylmethylhydroxypyridine Succinate Use in Patients with Stroke and Its Consequences. Rational Pharmacotherapy in Cardiology. 2014;10(4):448-456. https://doi.org/10.20996/18196446-2014-10-4-448-456.

16. El-Hattab AW, Zarante AM, Almannai M, Scaglia F. Therapies for mitochondrial diseases and current clinical trials. Mol Genet Metab. 2017;122(3):1-9. https://doi. org/10.1016/j.ymgme.2017.09.009.

17. Enns GM. Advances in Mitochondrial Medicine. J Inborn Errors Metab Screen. 2018;6:232640981775296. https:// doi.org/10.1177/2326409817752961.

18. Evtushenko SK. Metabolic (mitochondrial) stroke in children. International neurological journal. 2008;18(2):87-95. (In Russ.)

19. Finsterer J, Bindu PS. Therapeutic strategies for mitochondrial disorders. Pediatr Neurol. 2015;52(3):302-313. https://doi.org/10.1016/j.pediatrneurol.2014.06.023.

20. Garcia-Corzo L, Luna-Sanchez M, Doerrier C, et al. Ubiquinol-10 ameliorates mitochondrial encephalopathy associated with $\mathrm{CoQ}$ deficiency. Biochim Biophys Acta. 2014;1842(7):893-901. https://doi.org/10.1016/j.bbadis.2014.02.008.

21. Gimoyan LG, Silvanyan GG. The use of mildronate in the treatment of cognitive impairment in vascular dementia. Russian Medical Journal. 2017;21(5):1518-1524. (In Russ.)

22. Hirano M, Emmanuele V, Quinzii CM. Emerging therapies for mitochondrial diseases. Essays Biochem. 2018;62(3): 467-481. https://doi.org/10.1042/EBC20170114.

23. Ivkin DYu, Okovity SV. Pathogenic therapy of organ and tissue hypoxia at cellular level. Practitioner. 2017;2(7): 11-16. (In Russ.)

24. Joost K, Rodenburg RJ, Piirsoo A, et al. A Diagnostic Algorithm for Mitochondrial Disorders in Estonian Children. Mol Syndromol. 2012;3(3):113-119. https://doi. org/10.1159/000341375.

25. Kanabus M, Heales SJ, Rahman S. Development of pharmacological strategies for mitochondrial disorders. $\mathrm{Br} J$ Pharmacol. 2014;171(8):1798-1817. https://doi. org/10.1111/bph.12456.

26. Kerr DS. Review of clinical trials for mitochondrial disorders: 1997-2012. Neurotherapeutics. 2013;10(2):307-319. https://doi.org/10.1007/s13311-013-0176-7.
27. Leontyeva IV, Nikolaeva EA. Mitochondrial cardiomyopathies. Russian Bulletin of Perinatology and Pediatrics. 2016;61(3):22-30. https://doi.org/10.21508/1027-40652016-61-3-22-30.

28. Levchenkova OS, Novikov VE. Antihypoxants: possible mechanisms of action and their clinical uses. Vestnik of the Smolensk state medical Academy. 2011;10(4):43-57. (In Russ.)

29. Levchenkova OS, Novikov VE, Pozhilova YV. Pharmacodynamics of Antihypoxants and Their Clinical Use. Reviews on Clinical Pharmacology and Drug Therapy. 2012;10(3):3-12. https://doi.org/10.17816/rcf1033-12.

30. Levchenkova OS, Novikov VE, Pozhilova EV. Mitochondrial pore as a target of pharmacological action. Bulletin of the Smolensk state medical Academy. 2014;13(4):24-33. (In Russ.)

31. Lukyanova LD, Kirova YI, Germanova EL. The Role of Succinate in Regulation of Immediate HIF-1alpha Expression in Hypoxia. Bull Exp Biol Med. 2018;164(3):298-303. https://doi.org/10.1007/s10517-018-3976-2.

32. Martikainen $\mathrm{MH}$, Chinnery PF. Mitochondrial disease: mimics and chameleons. Pract Neurol. 2015;15(6):424-435. https://doi.org/10.1136/practneurol-2015-001191.

33. McCormick EM, Zolkipli-Cunningham Z, Falk MJ. Mitochondrial disease genetics update: recent insights into the molecular diagnosis and expanding phenotype of primary mitochondrial disease. Curr Opin Pediatr. 2018;30(6):714-724. https://doi.org/10.1097/MOP.0000000000000686.

34. Medvedev OS, Kalenikova El, Gorodetskaya EA, et al. Coenzyme Q10 in cardiology practice-theoretical foundations and results of clinical studies. Russian medical journal. 2009;17(18):1177-1181. (In Russ.)

35. Muranova AV, Strokov IA. Mitochondrial Cytopathies: Melas and Midd Syndromes. One Genetic Defect - Different Clinical Appearances. Neurol J. 2017;22(1):19-24. https://doi.org/10.18821/1560-9545-2017-22-1-19-24.

36. Murayama K, Shimura M, Liu Z, et al. Recent topics: the diagnosis, molecular genesis, and treatment of mitochondrial diseases. J Hum Genet. 2019;64(2):113-125. https://doi.org/10.1038/s10038-018-0528-6.

37. Nikolaeva EA, Semyachkina AN. Modern Possibilities of Hereditary Diseases Treatment in Children. Rossiyskiy Vestnik Perinatologii i Pediatrii (Russian Bulletin of Perinatology and Pediatrics). 2018;63(4):6-14. https://doi. org/10.21508/1027-4065-2018-63-4-6-14.

38. Novikov VE. Possibilities of pharmacological neuroprotection in the brain trauma. Psychopharmacology and biological narcology. 2007;7(2):1500-1509. (In Russ).

39. Novikov VE, Klimkina El. Effect of hypoxen on morphofunctional state of the liver in exogenous intoxication. Experimental and clinical pharmacology. 2009;72(5):43-45. (In Russ).

40. Novikov VE, Levchenkova OS. Promising directions of search for antihypoxants and targets of their action. Experimental and clinical pharmacology. 2013;76(5):37-47. (In Russ.)

41. Novikov VE, Levchenkova OS, Pozhilova YV. Role of reactive oxygen species in cell physiology and pathology and their pharmacological regulation. Reviews on Clinical Pharmacology and Drug Therapy. 2014;12(4):13-21. https://doi.org/10.17816/rcf12413-21. 
42. Novikov VE, Levchenkova OS. Mitochondrial targets for pharmacological regulation of cell adaptation to hypoxia. Reviews on Clinical Pharmacology and Drug Therapy. 2014;12(2):28-35. https://doi.org/10.17816/rcf12228-35.

43. Novikov VE, Levchenkova OS, Pozhilova EV. Mitochondrial nitric oxide synthase and its role in the mechanisms of cell adaptation to hypoxia. Reviews on Clinical Pharmacology and Drug Therapy. 2016;14(2):38-46. https://doi. org/10.17816/rcf14238-46.

44. Odinak MM, Yanishevskii SN, Tsygan NV, et al. Use of Succinates for Correction of Metabolic Impairments in the Ischemic Penumbra Zone in Stroke Patients. Neuroscience and Behavioral Physiology. 2015;45(5):600-604. https://doi.org/10.1007/s11055-015-0118-4.

45. Okovity SV, Sukhanov DS, Zaplutanov VA, Smagina AN. Antihypoxants in current clinical practice. Clinical medicine. 2012;16(9):63-68. (In Russ.)

46. Osmanov IM, Sukhorukov VS, Kalambet El. Coenzyme Q10 in pediatrics. Current pediatrics. 2011;10(2):146-149. (In Russ.)

47. Popov SV, Sivak KV, Guseinov RG, et al. Renoprotective activity of fumarate-containing infusion solution during ischemia - reperfusion of the kidney (experimental study). Experimental and clinical urology. 2014;7(3):14-18. (In Russ.)

48. Pozhilova EV, Novikov VE, Novikova AV. Pharmacodynamics and clinical applications of preparations based on hydroxypyridine. Bulletin of the Smolensk state medical academy. 2013;12(3):56-66. (In Russ.)

49. Pozhilova YV, Novikov VE, Levchenkova OS. The regulatory role of mitochondrial pora and the possibility of its pharmacological modulation. Reviews on Clinical Pharmacology and Drug Therapy. 2014;12(3):13-19. https:// doi.org/10.17816/rcf12313-19.

50. Pozhilova EV, Novikov VE, Levchenkova OS. Reactive oxygen species in cell physiology and pathology. Bulletin of the Smolensk state medical academy. 2015;14(2):13-22. (In Russ).

51. Pogilova EV, Novikov VE, Levchenkova OS. The mitochondrial ATP-dependent potassium channel and its pharmacological modulators. Reviews on Clinical Pharmacology and Drug Therapy. 2016;14(1):29-36. https://doi. org/10.17816/rcf14129-36. (In Russ).

52. Pupure J, Isajevs S, Skapare E, et al. Neuroprotective properties of mildronate, a mitochondria-targeted small molecule. Neurosci Lett. 2010;470(2):100-105. https:// doi.org/10.1016/j.neulet.2009.12.055.

53. Puusepp S, Reinson K, Pajusalu S, et al. Effectiveness of whole exome sequencing in unsolved patients with a clinical suspicion of a mitochondrial disorder in Estonia. Mol Genet Metab Rep. 2018;15:80-89. https://doi. org/10.1016/j.ymgmr.2018.03.004.

54. Rachin AP, Averchenkova AA. Idebenone (noben) - from theory to practice. Zh Nevrol Psikhiatr Im S.S. Korsakov. 2011;111(5):81-84. (In Russ.)

55. Radelfahr F, Klopstock T. [Diagnostic and Therapeutic Approaches for Mitochondrial Diseases]. Fortschr Neurol Psychiatr. 2018;86(9):584-591. https://doi.org/10. 1055/a-0621-9255.
56. Rai PK, Russell OM, Lightowlers RN, Turnbull DM. Potential compounds for the treatment of mitochondrial disease. Br Med Bull. 2015;116:5-18. https://doi.org/10.1093/ bmb/ldv046.

57. Romashchenko OV. Influence of trimetazidine on mitochondrial activity of patients with the stable angina pectoris. Scientific bulletins of Belgorod State University. Series: Medicine. Pharmacia. 2014;25(4):111-115. (In Russ.)

58. Russo E, Nguyen $\mathrm{H}$, Lippert $\mathrm{T}$, et al. Mitochondrial targeting as a novel therapy for stroke. Brain Circ. 2018;4(3):84-94. https://doi.org/10.4103/bc.bc_14_18.

59. Samoilenko IG, Khapchenkova DS, Tkachenko EV, Sokolova YuV. Clinical case of Leigh syndrome in an infant. International neurological journal. 2017;4(2):80-84. (In Russ.)

60. Scarpelli M, Todeschini A, Volonghi I, et al. Mitochondrial diseases: advances and issues. Appl Clin Genet. 2017;10:21-26. https://doi.org/10.2147/TACG.S94267.

61. Shabanov PD, Zarubina IV. Hypoxia and antihypoxants, focus on brain injury. Reviews on Clinical Pharmacology and Drug Therapy. 2019;17(1):7-16. https://doi. org/10.17816/rcf1717-16. (In Russ.)

62. Smirnov AV, Nesterova OB, Golubev RV. Succinic acid and its application in medicine. Part I. Succinic acid: metabolite and regulator of metabolism of the human body. Nephrology (Saint Petersburg). 2014;18(2):33-41. (In Russ.)

63. Statsenko ME, Turkina SV, Tyshchenko IA, et al. Potentials for the drug correction of secondary mitochondrial dysfunction in patients with coronary artery disease and comorbid pathology. Pharmateca. 2017;339(6):75-80. (In Russ.)

64. Steggall A, Mordi IR, Lang CC. Targeting Metabolic Modulation and Mitochondrial Dysfunction in the Treatment of Heart Failure. Diseases. 2017;5(2). https://doi. org/10.3390/diseases5020014.

65. Sukhorukov VS. To the development of rational bases of energy therapy. Rational Pharmacotherapy. 2007;21(2):40-47. (In Russ.)

66. Tarnopolsky MA. Creatine as a therapeutic strategy for myopathies. Amino Acids. 2011;40(5):1397-1407. https:// doi.org/10.1007/s00726-011-0876-4.

67. Tsaregorodtsev AD, Sukhorukov VS. Mitochondrial medicine: problems and tasks. Ros Vest Perinatol i Pediatr. 2012;57(4-2):4-13. (In Russ.)

68. Usenko LV, Tsariov OV. Modern Opportunities of Energy Protection in Critical States. Emergency Medicine. 2016;0(4.75):72. https://doi.org/10.22141/2224-0586.4. 75.2016 .75820 .

69. Valero T. Editorial (Thematic Issue: Mitochondrial Biogenesis: Pharmacological Approaches). Curr Pharm Des. 2014;20(35):5507-5509. https://doi.org/10.2174/13816 1282035140911142118.

70. Varga NA, Pentelenyi K, Balicza P, et al. Mitochondrial dysfunction and autism: comprehensive genetic analyses of children with autism and mtDNA deletion. Behav Brain Funct. 2018;14(1):4. https://doi.org/10.1186/s12993-018-0135-x.

71. Vasyuk YuA, Kulikov KG, Kudryakov ON, et al. Secondary mitochondrial dysfunction in acute coronary syndrome. Russian medical journal. 2007;8(5):49-51. (In Russ.)

72. Vorobieva VV, Shabanov PD, Proshin SN. Correction of mitochondrial dysfunction of rabbit cardiomyocytes using 
substrate antihypoxants. Pediatrician. 2015;6(3):74-80. (In Russ.)

73. Voronina TA. Mexidol: the spectrum of pharmacological effects. Zh Nevrol Psikhiatr im S.S. Korsakovav. 2012;12(5):86-90. (In Russ.)

74. Voronkova AS, Litvinova NA, Nikolaeva EA, Sukhorukov VS. Rare variants of mitochondrial DNA in a child with encephalomyopathy. Russian Bulletin of Perinatology and Pediatrics. 2016;61(5):42-46. https://doi.org/10.21508/10274065-2016-61-5-42-46.

75. Yamin MA, Chernikova IV, Araslanova LV, Shevkun PA. Mitochondrial encephalopathy, lactic acidosis, and stroke- like episodes syndrome (MELAS): diagnostic criteria, features of epileptic seizures, and treatment approaches by the example of a clinical case. Neurology, Neuropsychiatry, Psychosomatics. 2017;9(4):65-69. https://doi. org/10.14412/2074-2711-2017-4-65-69.

76. Ylikallio E, Suomalainen A. Mechanisms of mitochondrial diseases. Ann Med. 2012;44(1):41-59. https://doi.org/10. 3109/07853890.2011.598547.

77. Zhulev NM, Zuev AA, Saykova LA, Zuev AA. The use of Mexidol in the treatment of patients with hereditary neuromuscular diseases. Bull Exp Biol Med. 2006;70(1):22-27. (In Russ.)

\section{- Information about the authors}

Vasiliy E. Novikov - Doctor of Medical Sciences, Professor, Head of the Pharmacology Department. Smolensk State Medical University, Smolensk, Russia. E-mail: novikov.farm@yandex.ru.

Olga S. Levchenkova - PhD (Pharmacology), Assistant Professor, Pharmacology Department. Smolensk State Medical University, Smolensk, Russia. E-mail: levchenkova-o@yandex.ru.

Elena N. Ivantsova $-5^{\text {th }}$ year Student, Faculty of Pediatrics. Smolensk State Medical University, Smolensk, Russia. E-mail: elena. iwanczowa-lena@yandex.ru.

Victoria V. Vorobieva - Doctor of Medical Sciences, Assistant Professor, Pharmacology Department. S.M. Kirov Military Medical Academy, Saint Petersburg, Russia. E-mail: v.v.vorobeva@ mail.ru.
- Информация об авторах

Василий Егорович Новиков - д-р мед. наук, профессор, заведующий кафедрой фармакологии. ФГБОУ ВО «Смоленский государственный медицинский университет» Минздрава России, Смоленск. E-mail: novikov.farm@yandex.ru.

Ольга Сергеевна Левченкова - канд. мед. наук, доцент кафедры фармакологии. ФГБОУ ВО «Смоленский государственный медицинский университет» Минздрава России, Смоленск. E-mail: levchenkova-о@yandex.ru.

Елена Николаевна Иванцова - студент 5-го курса педиатрического факультета. ФГБОУ ВО «Смоленский государственный медицинский университет» Минздрава России, Смоленск. E-mail: elena.iwanczowa-lena@yandex.ru.

Виктория Владимировна Воробьева - д-р мед. наук, старший преподаватель кафедры фармакологии. ФГБВОУ ВО «Военномедицинская академия им. С.М. Кирова» Минобороны России, Санкт-Петербург. E-mail: v.v.vorobeva@mail.ru. 